\title{
Research and Thinking on College English Teaching Reform Based on Applied Talents Training Mode
}

\author{
Dan Zhao \\ Xijing University, Xi'an Shaanxi Province, China, 710123 \\ Keywords: Applied Talent Training Mode; College English; Teaching Reform; Research \\ Thinking \\ Abstract: The improvement of teaching level has provided a solid foundation and strong \\ support for the sustained and healthy development of the economy. In the past, the English \\ teaching mode of colleges and universities was inconsistent with the current development \\ trend of the times, and it is necessary to intensify the innovation of teaching purposes and \\ methods. The purpose of college English teaching reform is to cultivate applied talents, \\ take social needs as the core, innovate college English teaching, fundamentally improve the \\ level of English teaching, cultivate more applied talents, and promote the reform and \\ development of college English teaching.
}

At present, the number of applied talents has decreased drastically, and colleges are places to cultivate applied talents, adapt to current market development trends and requirements, innovate and reform existing English teaching models, and cultivate application-oriented talents that meet social requirements.

\section{The Significance of Applied Talents Training Mode to College English Teaching Reform}

\subsection{Comprehensively deepen teaching reform}

In the process of college education, English teaching is an important part of it, and it needs to be consistent with the teaching standards and plans of colleges. . In recent years, various colleges in China have conducted in-depth research and discussion on English teaching reform, thus improving the quality of education. Therefore, the implementation of English teaching reform must not only keep pace with the development of the times, but also put the teaching policies of colleges into place. College students must have a strong English language foundation and lay the foundation for later development.

\subsection{The society urgently needs application talents}

With the rapid development of modern society, the competition among enterprises has accelerated, and it has gradually tending to become white-hot. If enterprises want to survive and develop better, they must employ excellent talents. In this regard, the demand for talents from society and enterprises is increasing, and it is necessary to have diligent thinking, strong operational 
skills, and rich practical experience. It is the only way for the development of the times to better adapt to the market economy. Therefore, the relevant education departments in China attach great importance to the reform of English teaching. English is a lingua franca and is very important, especially for listening, speaking, reading and writing.

\subsection{The quality of applied talent training is closely related to student development}

In recent years, the number and scope of enrollment in higher education in China has been continuously broadened. Many graduates have begun to go to university life. There are also significant differences in the basic level of English for students. The English skills are scattered and will directly affect the future work of students. Therefore, schools must strengthen the cultivation of applied talents, which is an important part of college English teaching. English teaching reform can help solve English problems, improve students' English skills in the teaching process, and help students to get into work in the future.

\section{The Reform of College English Teaching under the Mode of Applied Talents Training}

\subsection{Monotonous curriculum}

The curriculum has a direct impact on the development direction of college English teaching. According to the current situation, the comprehensive course is one of the most used English courses in many universities. In the establishment of a diversified English curriculum system, it does not combine the characteristics of the school itself and the individualization requirements of the students. The curriculum is monotonous, it is difficult to promote the teaching method according to the aptitude, and it does not help the students' enthusiasm for learning English. The material is backward, the teaching content is not related to the content of modern society, and it cannot keep up with the development of the times. The teaching content is lacking in novelty. When students are learning English, they do not involve social topics. They are relatively vague about the social elements, and they do not appreciate the abundance of teaching content, which hampers the improvement of students' English skills. Too much emphasis on the promotion of English knowledge, neglecting the innovation of social development and teaching content, reducing the applicability and applicability of English teaching. When students step into the workplace, it is difficult to integrate the English knowledge and job requirements they have learned, and it is more difficult to improve the quality of students.

\subsection{Teaching mode is rigid}

The teaching effect is influenced by the teaching mode. In the middle stage of college English teaching reform, some educators are still bound by traditional ideas. Think of yourself as the main body of the classroom, and teach according to the plan of your own planning. Most of the time in the classroom is used to explain vocabulary, grammar and sentence patterns. Students do not have enough time to communicate and reduce student participation. Although colleges and universities employ many young teachers, these young teachers are influenced by traditional concepts and do not innovate teaching methods in a timely manner. Too much emphasis on student test scores and language knowledge, neglecting students to apply energy conservation. The teaching model is rigid and cannot fully stimulate students' enthusiasm for learning, too much emphasis on textbook content will make it impossible for students with poor learning to keep up, and students who have good studies will not learn knowledge, after a long time, English teaching is like a pool of stagnant water. 


\subsection{Insufficient application}

In order to improve language skills in listening and speaking, it is necessary to learn and accumulate over a long period of time, from identifying learning links to applying learning links. In college teaching, English is a compulsory course. However, it is not enough to study English twice a week. Many teachers only value their control role in the teaching process and do not guide students to join the English learning ranks. Leading students in the classroom, it takes a lot of time to learn literacy English, the effect of listening and speaking is not obvious. Among the students' English learning ability, listening, speaking, reading and writing are their core elements. The principle of listening and speaking is not implemented. The teaching of dumb English continues from previous education to higher education. In the student practice activities, student only know English and can write words, but cannot understand English and read the tone. Students' poor ability in listening and speaking has hampered English application ability, and there is no sense of existence in practice activities, resulting in students not enjoying learning English.

\section{College English Teaching Reform Strategy under the Mode of Applied Talents Training}

\subsection{Building a diversified English curriculum system}

Increasing the innovation of college English curriculum system plays a decisive role in the reform of college English teaching. In the English teaching of colleges based on the application-oriented talent training mode, teachers should pay attention to the diversified English curriculum system. Combine the details of the application-oriented talent development goals and transform the monotonous curriculum system. College English teaching can't just focus on the knowledge base, ignore the application, and can't just focus on theory and ignore practice. In the construction of diversified college English curriculum system, improving students' application skills is the most important part of curriculum system design. Integrating college English teaching with student majors makes English a part of students and let students use it better in learning and practice. For example, in the lower grades, colleges should add a basic English course to enrich the basic knowledge of students' English, familiarize students with key vocabulary and grammar knowledge, and lay a solid foundation for students' later study. For senior students, colleges must carry out specialized English courses according to the type of school major. Secretarial majors add secretarial English, and computer majors add computer English. Setting up a specialized English course will enable students familiar with the professional vocabulary they have learned and to upgrade their professional learning skills to become bilingual professional learning. This kind of curriculum has certain characteristics, solid students' English foundation, improve students' professional cognitive ability and learning ability, expand the application scope of English knowledge, and improve the overall quality of students.

\subsection{Pay attention to the change of English teaching mode}

Change the English teaching mode of colleges, focus on the training of students' application skills, activate the classroom atmosphere, and regard students as the main body of the classroom. Teachers should understand the talents needed in the current society, set up the content of classroom teaching in combination with the requirements of social industry and professional positions, clarify the purpose of teaching, and rationally distribute teaching content. Adjust the classroom teaching methods to promote the healthy development of students. In the teaching stage, the teacher should take the students as the main body to carry out teaching practice activities and strengthen the cultivation of students' application ability. In the classroom, the teacher is the instructor of the 
teaching activities, the adviser, the regulators, the collaborators and progress with the students. In the traditional listening teaching process, teachers can play listening audio, so that students can practice listening better. When correcting the answer, the teacher will pause the player and listen to a pause to facilitate the student to learn better. This kind of teaching mode is too rigid and wastes time, making it difficult for students to concentrate. When students develop application skills, teachers must be brave in innovative teaching models and increase reform efforts. For example, when learning the following content “Tongzhou To Be Beijing's Second CenterBeijing's city government recently said that it is going to move part of its administrative functions out of the city center to Tongzhou as part of a plan to better integrate the Chinese capital with its surrounding areas.As the second administrative center in the government's planning, Tongzhou has drawn unprecedented attention from people." students only need to answer "What does Beijing government plan to do?”. Breaking through the traditional listening teaching mode, teachers can also innovate teaching modes through the integration of listening and writing. When developing students' input language and applied language, teachers should actively encourage students to obtain hearing messages, organize their language according to their own ideas, and submit a notice. This will not only improve the students' listening skills, but also use the students' style writing knowledge to lay a solid foundation for students to step into the workplace.

\subsection{Building an interactive teacher-student relationship}

Based on the application-oriented talent training model, teachers should pay attention to the reform of teacher-student relationship. Build an interactive teacher-student relationship so that students can listen carefully in the classroom and express their own views. The cultivation of students' listening and speaking abilities has gradually become the focus of the class, regard students as the main body. The primary task of college English teaching reform is to innovate the relationship between teachers and students, so that they can be harmonious and equal, so teachers can use the media to strengthen communication with students. In the classroom, teacher-student interaction is important, and the communication between students and students is equally important. It can create a warm classroom atmosphere for students and exchange English key points in the classroom. In the process of interaction, It can stimulate students' thinking mode and create learning and development opportunities for students. In the interactive classroom, students not only listen to and take notes, but also give full play to students' initiative. Let the students integrate into the English interaction, so that the teacher can further grasp the students' attitudes towards learning English and the level of English application ability, correctly guide the students, and promote students to turn knowledge into abilities. In the process of oral teaching, according to the questions asked by the teacher, such as "what do you like to do on Sunday?" the response of the students is different. Students who are more capable of speaking, they will be able to express their thoughts and be brave in expressing the topic that is closely related to life. Students who have poor oral English skills do not know how to express it, whenever they hear a teacher asking to practice oral content, their mood will be very anxious and repellent. In the classroom teaching, teachers should constantly encourage and evaluate the interaction between students and students, so that students can better understand their English skills and potential to improve their self-confidence. Some students' answers are "What do I like to do on Sunday? Well, I think it's changing every Sunday. I like to go see some exhibits, art exhibitions or things like that. I like to go to the cinema. I like to stay home when it's really rainy" this kind of answer, the language is very smooth and there is no embarrassment, at this time, the teacher should praise the students and guide other students to learn from these students and express them boldly. In the evaluation process, the teacher should evaluate according to the student's learning situation, and cannot use the same standard to ask everyone. If 
the students with poor speaking ability say "I read books and finish my homework", In this kind of simple answer, the teacher should actively guide the student, questions like "What books do you like?" help students to make more details in a simpler language, so that students can find the best way to communicate in spoken English.

\subsection{Strengthen the construction of the teaching staff}

The strong teacher team has significantly improved the quality and effectiveness of English teaching in colleges. If some colleges do not have teacher team, it will constrain the cultivation of English applied talents and limit their development. In this regard, it is necessary to strengthen the construction of teacher team, so that colleges can cultivate more applied talents and meet the needs of social development. When constructing a professional English teacher team with strong professional quality, high level and full of vitality, the primary task is to formulate a reasonable policy, actively introduce young English teachers with new educational ideas and concepts, and then expand the English teacher team. In the process of introducing young teachers, we must regularly train existing teachers to strengthen their professional knowledge, comprehensive quality and innovative ideas. At the same time, in improving the professional knowledge ability of college English teachers, we must also focus on cultivating teachers' educational thoughts and concepts. Stabilize the teaching staff, improve the level of English teaching, and cultivate more excellent applied talents.

\section{Conclusion}

In summary, with the continuous development of social economy, college English teaching reform has achieved remarkable results, realized the problems of college English teaching, and proposed corresponding teaching reform programs, intensified practice, explore a path of college English teaching reform with the characteristics of talent cultivation. Pay attention to the comprehensive quality of college students, innovate teaching content and teaching mode, and improve students' English proficiency.

\section{Acknowledgment}

The Foundation Project of the 13th Five-year Planning Project of Education and Science in Shaanxi Province: Research on the Cultivation Mode of English Applied Talents in Private Universities Based on the "Guidance System of Harvard University”, SGH17H407

\section{References}

[1] Jing Xiao. Research on College English Teaching Model in Higher Vocational Colleges Based on Professional Ability [J]. China High-tech Zone, 2017, (20):152-155.

[2] Yongfang Li. Analysis of English Teaching Reform and Innovation under the Mode of Applied Talents Training [J]. English Square, 2016, (3):132-133.

[3] Yingying Jiang, Ximin Ji. Research on College English Teaching Reform under the Mode of Applied Talents Training [J]. Journal of Jilin Province College of Education, 2015,(2):105-107.

[4] Shuguang Zhang. Exploration on the Reform of College English Teaching under the Mode of Applied Talents Training [J]. English Square,2017,(4):108-109.

[5] Furong Zhang. Research on the Current Situation and Reform Countermeasures of College English Teaching Based on the Concept of Applied Talents Training [J]. Talent, 2017,(29):148-149.

[6] Yuhua Dai, You Zhang, Fei Che. Research on Teaching Reform of Professional English under the Mode of High-Quality Applied Talents Training [J]. Education and teaching forum, 2017,(47):91-92.

[7] Qiaoyan Liu. Research and Practice on Comprehensive Reform of College English Course under the Mode of Applied Talents Training [J]. Examination weekly, 2017,(4):10-11. 
[8] Yuan Wang. Construction of College English Teaching Evaluation System under the Mode of Applied Talents Training [J]. Educational modernization, 2017, (13):16-17. 